\title{
Aktivno suočavanje adolescenata sa stresom kao rezultat zadovoljstva obiteljskim interakcijama
}

\author{
Marko Romić* \\ romicmarko@hotmail.com \\ https://orcid.org/0000-0002-8337-7051 \\ Maja Ljubetić* ${ }^{*}$ \\ ljubetic@ffst.hr \\ https://orcid.org/0000-0002-9344-5580
}

https://doi.org/10.31192/np.19.2.15

UDK: 159.944.4-053.67:173.7

303.423:159.9

Izvorni znanstveni rad / Original scientific paper

Primljeno: 16. veljače 2021.

Prihvaćeno: 9. travnja 2021.

Razumijevanje medusobnih odnosa u obitelji jedan je od ključnih uvjeta boljeg razumijevanja pojedinca $i$ njegovih bitnih odrednica. Kvaliteta obiteljskih interakcija i obiteljsko ozračje određuju neke bitne značajke pojedinca, kakav je i aktivan ili pasivan način suočavanja sa stresom. Aktivno suočavanje podrazumijeva izbor strategija izravno usmjerenih na rješavanje problema, dok se pasivno suočavanje odnosi na primjerice, izbjegavanje, okretanje religiji, mašta $i$ sl. Da bi se dobili odgovori na pitanje odnosa kvalitete obiteljskih interakcija $i$ načina suočavanja sa stresom adolescenata poduzeto je istraživanje na uzorku od 406 sudionika prosječne dobi od 21 godine. Rezultati istraživanja pokazuju da kvaliteta obiteljskih interakcija značajno utječe na način na koji se adolescenti suočavaju sa stresom i to tako da veće zadovoljstvo obiteljskim interakcijama istodobno znači i češće suočavanje sa stresom usmjereno na problem.

Ključne riječi: adolescenti, obiteljske interakcije, stres, suočavanje sa stresom.

\section{Uvod}

Adolescencija je prijelazno razdoblje velikih fizičkih i emocionalnih promjena koje mogu rezultirati značajnim psihološkim stresom za mlade. Kombinacija mnoštva čimbenika, poput zahtjeva škole, akademskog pritiska, tjeskobe u vezi s budućnosti, odnosa u obitelji i s vršnjacima, izaziva tjeskobu kod ado-

\footnotetext{
* Dr. sc. Marko Romić, Centar za mentalno zdravlje, Hrvatskih branitelja bb, BiH-88000 Mostar, Bosna i Hercegovina.

*** Prof. dr. sc. Maja Ljubetić, Sveučilište u Splitu, Filozofski fakultet; Poljička cesta 35, HR-21000 Split.
} 
lescenata. Strategija suočavanja sa stresom koje pojedinci koriste uvelike ovisi o njihovu kognitivnom i emocionalnom razvoju. Adaptivno suočavanje često omogućuje razvoj emocionalno zdravih osoba, dok neprilagođeno suočavanje može dovesti do destruktivnih ponašanja adolescenata. ${ }^{1}$

Adolescenti imaju poteškoća u suočavanju sa životnim izazovima i njihovim upravljanjem, što kod njih često izaziva stres, ${ }^{2}$ čiji učinak može biti posebno štetan za njihovu psihološku i fiziološku dobrobit. ${ }^{3}$ Jedna od multikulturalnih analiza izvora stresa kod adolescenata pokazala je da su akademska postignuća i roditeljska kontrola za njih najvažniji uzroci stresa, dok su problemi s vršnjacima i emocionalnim vezama manji. ${ }^{4}$

Stresna iskustva, uključujući ključne životne događaje i uobičajene svakodnevne nedaće, ugrožavaju dobrobit adolescenata. Otprilike $25 \%$ njih doživjet će barem jedan značajan stresor, uključujući i smrt voljene osobe ili svjedočenje traumatičnom događaju. U usporedbi s djecom, adolescenti se češće susreću s mnogim novim, potencijalno prijetećim ili izazovnim socijalnim iskustvima koja su očekivana sve do kasnije adolescencije (dobi od 20 do 22 godine), a kada se najčešće događaju i značajne socijalne promjene (napuštanja kuće, izbor smjera obrazovanja ili karijere, stvaranje intimnih partnerskih odnosa i sl.). ${ }^{5}$

Evidentne su individualne razlike $u$ načinu na koji adolescenti reagiraju na stres, ali postoje i tipični obrasci ponašanja. Stručnjaci iz područja suočavanja sa stresom zaključili su da su vrlo česti pokušaji i ponašanja usmjerena na promjenu stresne situacije rješavanjem problema (aktivno suočavanje), ali se ona smanjuju tijekom adolescencije, dok se suočavanje usmjereno na emocije koristi sve više. ${ }^{6}$

$\mathrm{Na}$ temelju empirijskih dokaza predložena su dva stila suočavanja sa stresom: suočavanje usmjereno na problem i suočavanje usmjereno na emocije. ${ }^{7}$ Prvo se odnosi na suočavanje s problemom, u kojem se pojedinac usredotočuje na rješavanje problema, što izaziva stresno iskustvo, dok se u drugom pristupu pojedinac suočava tako da se usredotočuje na reguliranje svojih emocija koje proizlaze iz iskustva stresa. Međutim, autori naglašavaju da ovaj dihotomni

${ }^{1}$ Usp. John SMITH, Stress and coping for adolescents. Stress and adolescence, James Cook University, 2013, 2-11.

${ }^{2}$ Usp. Lakyntiew PARIAT i dr., Stress Level of College Students. Interrelationship between Stressors and Coping Strategies, IOSR Journal of Humanities and Social Sciences, 19 (2014) 8, 4046.

${ }^{3}$ Usp. Rivka YAHAV, Miri COHEN, Evaluation of a cognitive-behavioral intervention for adolescents, International Journal of Stress Management, 15 (2008) 2, 173-188.

${ }^{4}$ Usp. Malte PERISKE, Inge SEIFFGE-KRENKE, Competence in coping with stress in adolescents from three regions of the world, Journal of Youth and Adolescence, 41 (2012) 7, 863-79.

${ }^{5}$ Usp. Melanie J. ZIMMER-GEMBECK, Ellen A. SKINNER, Adolescents' coping with stress. Development and diversity, Prevention Researcher, 15 (2008) 4, 3-7.

${ }^{6}$ Usp. Erica FRYDENBERG, Ramon LEWIS, Teaching coping to adolescents. When and to whom?, American Educational Research Journal, 37 (2000) 3, 727-745.

7 Usp. Richard S. LAZARUS, Suzan FOLKMAN, Stress, appraisal, and coping, New York, Springer, 1984, 117-122. 
model može imati ograničenja, pri kategoriziranju različitih oblika suočavanja, od kojih se neka ne uklapaju u potpunosti ni u jedan od ova dva stila.

Također, stilovi suočavanja sa stresom i ponašanje opisani su na temelju ishoda kao adaptivni ili neadaptivni, ${ }^{8}$ što također, može biti dvojbeno. Istraživanja studentskih suočavanja sa stresom pokazala su da stilovi suočavanja koji se smatraju neprilagođenima ne moraju uvijek imati negativan ishod, jednako kao što i adaptivni stilovi ne moraju dosljedno uzrokovati pozitivan ishod. ${ }^{9}$

\section{Obiteljsko ozračje - potpora ili rizik}

Obiteljsko ozračje središnja je odrednica osjećaja subjektivne dobrobiti tijekom cijelog životnog vijeka, uključujući djetinjstvo i vrijeme adolescencije. ${ }^{10}$ Toplo i podržavajuće obiteljsko ozračje stvara pozitivnu energiju među članovima obitelji stoga, vrlo je važno da roditelji s djecom i adolescentima komuniciraju otvoreno i učinkovito. ${ }^{11}$

Nekoliko studija koje su se bavile međuodnosom percepcije odnosa s roditeljima i strategija suočavanja sa stresom kod adolescenata pokazalo je da topao odnos i pozitivna komunikacija roditelja s djecom uzrokuju češće suočavanje sa stresom rješavanjem problema. ${ }^{12}$ Dakle, percipirana roditeljska toplina pozitivno je povezana s aktivnim suočavanjem sa stresom. ${ }^{13}$ Druga istraživanja ukazuju na to da percepcija odnosa s roditeljima utječe na strategije suočavanja adolescenata sa stresom ovisno o njihovu spolu i dobi. Osjećaj da ih roditelji vole i cijene omogućuje razvoj funkcionalnih strategija suočavanja, dok je roditeljska patološka kontrola povezana s neprilagođenim ili nefunkcionalnim strategijama suočavanja sa stresom. ${ }^{14}$ Suprotno, percepcija nemara roditelja izaziva suočavanje sa stresom izbjegavanjem i nedostatkom odgovornosti adolescenata. Kada se adolescenti osjećaju prihvaćenima, razvijaju funkcionalno ponašanje u suočavanju sa stresom koristeći kognitivno rekonstruiranje, traženjem emo-

${ }^{8}$ Usp. Ruby R. BROUGHAM i dr., Stress, sex differences, and coping strategies among college students, Current Psychology, 28 (2009) 2, 85-97.

${ }^{9}$ Usp. Angela PALMER, Susan RODGER, Mindfulness, stress, and coping among university students, Canadian Journal of Counselling and Psychotherapy, 43 (2009) 3, 198-212.

${ }^{10}$ Usp. Marissa L. DIENER, Mary Beth DIENER McGAVRAN, What makes people happy? A developmental approach to the literature on family relationships and well-being, u: M. Eid, R. J. Larsen (ur.), The science of subjective well-being, New York, Guilford, 2008, 347-375.

${ }^{11}$ Usp. Toni MAGLICA, Obilježja roditeljstva i odnos roditelja prema kockanju kao prediktori kockanja muške djece, 2017, doktorska disertacija, Zagreb, Edukacijsko-rehabilitacijski fakultet Sveučilišta u Zagrebu, 25-26.

${ }^{12}$ Usp. Tomás P. CAYCHO, Relationship with parents and coping strategies in adolescents of Lima, Propósitos y Representaciones, 4 (2016) 1, 11-59.

${ }^{13}$ Usp. Uwe WOLFRADT, Perceived parenting styles, depersonalisation, anxiety and coping behaviour in adolescents, Personality and Individual Differences, 34 (2003) 3, 521-532.

${ }^{14}$ Usp. Maria Cristina RICHAUD DE MINZI, Stress and coping in adolescence, u: A. M. Columbus (ur.), Advances in Psychology Research, 45 (2006) 67-84. 
cionalne potpore i djelovanjem na izvor stresa. Istodobno, kada adolescenti percipiraju prihvaćanje roditelja, to im ne dopušta razvijanje disfunkcionalnog ponašanja u suočavanju sa stresom temeljenom na kognitivnom izbjegavanju, nedostatku kontrole i kognitivnim blokadama. ${ }^{15}$ Međutim, kada adolescenti doživljavaju odbacivanje roditelja, neprijateljstvo, okrivljavanje i ograničavanje autonomije, oni razvijaju disfunkcionalno ponašanje u suočavanju s izvorima stresa. Dok se prihvatljiva kontrola roditelja smatra vrlo važnom za pozitivan razvoj odnosa s adolescentima, pretjerana kontrola - koja ograničava autonomiju i sigurnost adolescenta - vrlo je negativna za njihovo uspješno suočavanje s izazovima. ${ }^{16}$

\section{Cilj i problemi istraživanja}

Cilj ovoga istraživanja bio je ispitivanje međuodnosa zadovoljstva obiteljskim interakcijama i načina suočavanja sa stresom adolescenata te dobivanje odgovora na istraživački upit: Koriste li češće suočavanje sa stresom usmjerenim na problem adolescenti koji su zadovoljniji obiteljskim interakcijama? Postavljena je polazna hipoteza: Adolescenti koji su zadovoljniji obiteljskim interakcijama češće koriste suočavanje sa stresom usmjereno na problem. U tu svrhu prikupljeni su podaci o: kontekstualnim varijablama, kvaliteti obiteljskih interakcija i stilovima suočavanja sa stresom adolescenata.

\section{Metoda istraživanja}

\subsection{Sudionici istraživanja}

Istraživanjem je obuhvaćen uzorak od 406 sudionika sa Sveučilišta u Mostaru. Primijenjeni su principi cluster uzorkovanja, jer su ispitanici grupirani u veće jedinice uzorka koje unutar sebe imaju neka zajednička obilježja. Uzorak je činilo 159 muških (39\%) i 247 (61 \%) ženskih sudionika istraživanja, prosječne dobi od 21 godine, od kojih najmlađi ima 18 godina, a najstariji 42 godine.

\footnotetext{
${ }^{15}$ Usp. Maria Cristina RICHAUD DE MINZI i dr., Un modelo acerca de la relación entre los vínculos interpersonales y el afrontamiento en la adolescencia, En M. C. Richaud y V. Lemos (ur.), Psicología y otras Ciencias del Comportamiento, Compendio de investigaciones actuales, 1 (2013) 1-2, 137-157.

${ }^{16}$ Usp. Tomás P. CAYCHO, Relationship with parents and coping strategies in adolescents of Lima, Propósitos y Representaciones, 4 (2016) 1, 11-59.
} 


\subsection{Mjerni instrumenti}

\section{Skala zadovoljstva obiteljskim interakcijama}

Skala zadovoljstva obiteljskim interakcijama je skala na kojoj ispitanici daju odgovore o tome kako se osjećaju u svojoj obitelji i kolik je stupanj zadovoljstva obiteljskim životom (primjeri: Za mene je obitelj izvor utjehe i zadovoljstva; U mojoj obitelji me nitko ne razumije). Ova skala dio je šire skale, odnosno ona je podskala Skale kvalitete obiteljskih interakcija $(\mathrm{KOBI})^{17}$ koja mjeri interakcije adolescenata i roditelja na dvije dimenzije, u literaturi najčešće opisane kao prihvaćanje (emocionalna toplina, intimnost) i odbacivanje (kontrola, emocionalno zanemarivanje). Ove dvije dimenzije su konceptualizirane u skladu s teorijom roditeljskog prihvaćanja i odbacivanja (PART - parenteral acceptance - rejection theory) Ronalda Rohnera ${ }^{18}$. Skala ima pet podskala: Zadovoljstvo vlastitom obitelji (primjer: Za mene je obitelj izvor utjehe i zadovoljstva), Prihvaćanja od majke (primjer: Majci se mogu obratiti za pomoć uvijek kad mi je teško), Prihvaćanje oca (primjer: Moj otac ulaže velike napore da bi meni bilo bolje), Odbacivanje majke (primjer: Mojoj majci nije važno što ja u stvari osjećam) i Odbacivanje oca (primjer: Moj otac pred mene postavlja nemoguće zahtjeve). Ispitanici na skali Likertova tipa procjenjuju (od $0=$ uopće ne, do $5=$ u potpunosti da) koliko se svaka od navedenih tvrdnji odnosi na njihov odnos s majkom, ocem ili obitelji kao cjelinom. Ukupan rezultat utvrđuje se za svaku podskalu posebno, a dobiva se jednostavnim zbrajanjem bodova.

U istraživanjima provedenim u Hrvatskoj utvrđeno je da je očevo odbacivanje onaj aspekt roditeljskog ponašanja koji je najviše povezan s različitim oblicima agresivnog, delikventnog i ovisničkog ponašanja, depresivnosti, anksioznosti i somatizacijom, te prilagodbom u školi i među vršnjacima kao i stavovima prema zlostavljanju..$^{19}$ Prema jednom istraživanju ${ }^{20}$ skala je pokazala zadovoljavajuće metrijske karakteristike (Cronbach alpha od 0,87 za podskalu Odbacivanja majke, do 0,89 za podskalu Prihvaćanje oca).

U ovom istraživanju skala Zadovoljstvo obiteljskim interakcijama je pokazala zadovoljavajuće metrijske vrijednosti. Cronbach alpha je 0,86. Validirane su i ostale podskale Skale kvaliteta obiteljskih interakcija te su pokazale zadovoljavajuće metrijske vrijednosti. Za podskalu Prihvaćanje majke Cronbach alpha je 0,83, Odbacivanje majke 0,87, Prihvaćanje oca 0,85, Odbacivanje oca 0,88, a pouzdanost skale promatrane kao cjelina pokazala se visokom (Cronbach alpha $0,92)$.

\footnotetext{
${ }^{17}$ Anita VULIĆ-PRTORIĆ, Somatizacija i kvaliteta obiteljskih interakcija kod djece i adolescenata, Medica Jadertina, 30 (2000) 1-2, 21-31.

${ }^{18}$ Ronald P. ROHNER, The warmth dimension. Foundations of parental acceptance-rejection, Beverly Hills, Sage Publications, 1986.

${ }^{19}$ Usp. Mira KLARIN, Odnosi u obitelji i s vršnjacima kao prediktori različitih aspekata prilagodbe u školi, Doktorska diseracija, Filozofski fakultet Sveučilišta u Zagrebu, Zagreb, 2000.

${ }^{20}$ Usp. Anita VULIĆ-PRTORIĆ, Priručnik za Skalu strahova i anksioznosti za djecu i adolescente SKAD-62, Jastrebarsko, Naklada Slap, 2004.
} 


\section{Skala suočavanja sa stresom usmjerenog na problem}

Skala suočavanja sa stresom usmjerenog na problem dio je Skale suočavanja sa stresnim situacijama (CISS - Coping inventory for stressful situations), ${ }^{21}$ koja ima tri podskale: Suočavanje usmjereno na emocije (primjer: Postajem jako napet), Suočavanje usmjereno na problem (primjer: Usmjerim se na problem da vidim kako bih ga riješio) i Izbjegavanje (primjer: Pokušavam to prespavati). Podskala Izbjegavanja ima dvije podskale: Distrakcije (izbjegavanje usmjeravanjem na nešto što nema veze s problemom izazvanim stresom, npr. Razgledavam izloge) i Socijalne diverzije (izbjegavanje usmjeravanjem k drugim ljudima iz okruženja, npr. Nastojim biti s drugim ljudima). Ispitanici su na skali od 5 stupnjeva procjenjivali koliko koriste određene vrste aktivnosti (1 - uopće ne do 5 - u potpunosti da) pri susretu s teškom, stresnom ili uznemirujućom situacijom. U istraživanjima provedenim u Hrvatskoj ${ }^{22}$ Cronbach alpha koeficijenti dobivenih triju podskala bili su zadovoljavajuće visoki $(0,85 ; 0,79$ i 0,71$)$.

Faktorska struktura cijelog upitnika provjerena je na našem uzorku. Nakon provedene faktorske analize po metodi zajedničkih faktora, korišteno je nekoliko kriterija za određivanje broja faktora na podskalama: (1) karakteristični korijen veći od 1; (2) analiza Scree Plota; (3) postotak objašnjene varijance pojedinog faktora i (4) interpretabilnost faktora. Za potrebe ovoga istraživanja napravljena je faktorska analiza s pretpostavljena tri i s pretpostavljena četiri faktora.

Analiza s pretpostavljena tri faktora, dala je faktorsku strukturu koja se djelomično razlikuje od one iz originalnog CISS upitnika Endlera i Parkera. ${ }^{23} \mathrm{U}$ prvom faktoru pojavljuju se ukupno 23 čestice, ali neke od njih imaju negativnu korelaciju s faktorom (Prekoravam se da ne znam što mi je činiti; »Sledim se« $i$ ne znam što činim; Isključujem se i izbjegavam situaciju), a neke se istovremeno pojavljuju u jednom od druga dva faktora. Jedna čestica, koja je u originalnom CISS upitniku bila dio Suočavanja usmjerenog na problem (Mijenjam redoslijed onoga što mi je bitno), na našem uzorku nema nikakvo faktorsko zasićenje. Konačno, za daljnje analize, ostavljeno je 16 čestica koje se sadržajno poklapaju sa Suočavanjem usmjerenim na problem. Faktorska zasićenost pojedinih čestica kreće se od 0,32 za česticu Nalazim nekoliko različitih rješenja problema do 0,64 za česticu Usmjerim se na problem da vidim kako bih ga riješio. Drugi faktor u ovom istraživanju ima 15 čestica, koje se sadržajno poklapaju sa Izbjegavanjem, ali pet čestica iz originalnog CISS upitnika je eliminirano stoga što se $\mathrm{s}$ istom ili većom faktorskom zasićenošću pojavljuju u jednom od ostala dva faktora. Faktorska zasićenost pojedinih čestica kreće se od 0,34 za česticu Idem

\footnotetext{
${ }^{21}$ Usp. Norman S. ENDLER, James D. PARKER, Multidimensional assessment of coping. A critical evaluation, Journal of Personality and Social Psychology, 58 (1990) 5, 844-854.

${ }^{22}$ Usp. Katica LACKOVIĆ-GRGIN, Izabela SORIĆ, Korelati prilagodbe studiju tijekom prve godine, Društvena istraživanja, 4-5 (1997) 30-31, 461-475.

${ }^{23}$ Usp. Endler, Parker, Multidimensional assessment of coping..., 848.
} 
prošetati do 0,80 za česticu Izlazim na piće $i$ jelo. Treći faktor, također, čini 15 čestica, koje se sadržajno poklapaju sa Suočavanjem usmjerenim na emocije, ali tri od njih pojavljuju se i u jednom od druga dva faktora, a dvije nemaju nikakvo faktorsko zasićenje na ovom uzorku (Prekoravam se zbog odugovlačenja; Iskalim se na drugim ljudima).

Budući da je analiza s pretpostavljena četiri faktora pokazala da drugi i četvrti faktor sadržajno odgovaraju izbjegavanju kao načinu suočavanja sa stresom, a uz to četvrti faktor sadrži samo pet čestica, od kojih jedna čestica ima faktorsko zasićenje samo 0,30 odlučeno je za daljnje analize primijeniti trofaktorsku strukturu upitnika, uz ostalo i stoga što je razlika u objašnjenoj varijanci neznatna $(0,35$ objašnjene varijance $u$ analizi sačetiri pretpostavljena faktora, u odnosu na 0,33 u trofaktorskoj strukturi). Tri izdvojena faktora su: (1) Suočavanje usmjereno na problem, koji ima 16 čestica, a objašnjava 0,12 varijance; (2) Izbjegavanje, koji ima 11 čestica, a objašnjava 0,11 varijance i (3) Suočavanje usmjereno na emocije, s 10 čestica, koji objašnjava 0,10 varijance. Sva tri faktora zajedno objašnjavaju 0,33 varijance. Ovakva skala ima zadovoljavajuće metrijske vrijednosti: Cronbach alpha je 0,85 za prvi faktor, 0,87 za drugi i 0,82 za treći faktor. Za potrebe ovoga rada korištena je podskala Suočavanje usmjereno na problem.

\subsection{Obrada podataka}

Radi ostvarenja postavljenog ciljeva i dobivanja odgovora na istraživački upit primijenjene su sljedeće metode i analize: metode deskriptivne statistike, hi-kvadrat test i faktorska analiza (za ispitivanje specifičnih faktora na pojedinim skalama i upitnicima).

\section{Rezultati i rasprava}

\subsection{Zadovoljstvo obiteljskim interakcijama}

Kvaliteta obiteljskih interakcija ispitana je Skalom zadovoljstva obiteljskim interakcijama, ${ }^{24}$ koja se sastoji od 11 čestica, s rasponom skale od 11 do 55 bodova, pri čemu veći broj bodova znači i veći stupanj zadovoljstva (tablica 1).

Tablica 1. Deskriptivni prikaz rezultata na skali Zadovoljstvo obiteljskim interakcijama

\begin{tabular}{|c|c|c|c|c|c|c|}
\hline $\mathbf{N}$ & Min & Max & M & SD & Koef. varijacije & Cronbach alpha \\
\hline 406 & 22 & 55 & 49,787 & 5,094 & $10 \%$ & 0,86 \\
\hline
\end{tabular}

\footnotetext{
${ }^{24}$ Vulić-Prtorić, Somatizacija i kvaliteta obiteljskih interakcija..., 25.
} 
Iz dobivenih rezultata (tablica 1) vidljivo je da ukupan prosječni rezultat zadovoljstva obiteljskim interakcijama sudionika istraživanja $(M=49,787)$ govori o visokom stupnju njihova zadovoljstva, pri čemu je raspon rezultata od 22 do 55 bodova. Raspon dobivenih rezultata podijeljen je u 5 kategorija, od nisko (od 22 do 28 bodova) do visoko (od 50 do 55 bodova), pri čemu manji broj bodova znači manji stupanj zadovoljstva obiteljskim interakcijama, a veći broj bodova znači i veći stupanj zadovoljstva (tablica 2). Samo jedan sudionik istraživanja ulazi u kategoriju niskog stupnja zadovoljstva obiteljskim interakcijama, a 9 (2 \%) sudionika istraživanja je u kategoriji umjereno niskog stupnja zadovoljstva. U kategoriji ni nizak, niti visok stupanj zadovoljstva obiteljskim interakcijama je 25 (6 \%) sudionika istraživanja, dok je u kategoriji umjereno visokog stupnja zadovoljstva njih 111 (26\%). Najviše sudionika istraživanja, njih 260 (64\%), je u kategoriji visokog zadovoljstva obiteljskim interakcijama (tablica 2). Dobiveni koeficijent varijacije (10 \%) i relativno malena standardna devijacija (SD = $5,094)$ ukazuju na relativno male razlike u načinu odgovaranja sudionika istraživanja, a unutarnja konzistencija, odnosno pouzdanost dobivenih podataka je zadovoljavajuća (Cronbach alpha $=0,86$ ).

Tablica 2. Raspon rezultata, frekvencije i postotci zastupljenosti sudionika istraživanja na skali Zadovoljstvo obiteljskim interakcijama

\begin{tabular}{|c|c|c|c|c|c|c|}
\hline $\begin{array}{c}\text { Zadovoljstvo obiteljskim } \\
\text { interakcijama }\end{array}$ & Nisko & $\begin{array}{c}\text { Umjereno } \\
\text { nisko }\end{array}$ & $\begin{array}{c}\text { Ni nisko, } \\
\text { niti visoko }\end{array}$ & $\begin{array}{c}\text { Umjereno } \\
\text { visoko }\end{array}$ & Visoko & Suma \\
\hline Raspon rezultata & $22-28$ & $29-35$ & $36-42$ & $43-49$ & $50-55$ & \\
\hline $\mathrm{f}$ & 1 & 9 & 25 & 111 & 260 & 406 \\
\hline$\%$ & 0 & 2 & 6 & 26 & 64 & 100 \\
\hline
\end{tabular}

Raspodjela rezultata dobivenih na skali Zadovoljstvo obiteljskim interakcijama nema karakter normalne raspodjele, kakvu bi se moglo očekivati na uzorcima ovakve veličine, nego imaju značajke pozitivne eksponencijalne raspodjele.

Uravnoteženo funkcioniranje cjelokupne obitelji uključuje umjerenu razinu kohezivnosti i fleksibilnosti, ravnotežu između bliskosti i individualnosti, ravnopravno vodstvo, demokratski pristup disciplini i korištenje pozitivnih komunikacijskih vještina ${ }^{25}$ te potiče dobru psihosocijalnu prilagodbu adolescenata. ${ }^{26}$ Nasuprot tome, obiteljska disfunkcionalnost povezana je s psihopatologijom adolescenata i to: poremećajima ponašanja, agresivnim, delikventnim ponašanjem, zlouporabom ili ovisnosti o psihoaktivnim tvarima ${ }^{27}$ i emocionalnim

\footnotetext{
${ }^{25}$ Usp. David H. OLSON, Dean M. GORALL, Circumplex model of marital and family systems, u: F. WALSH (ur.), Normal family processes. Growing diversity and complexity, New York, Guilford, 2003, 514-548.

${ }^{26}$ Usp. Carolyn S. HENRY i dr., Adolescent perceptions of overall family system, Journal of Child E Family Studies, 15 (2006) 3, 319- 329.

${ }^{27}$ Usp. Ross W. GREENE i dr., Psychiatric Comorbidity, Family Dysfunction, and Social Impairment in Referred Youth With Oppositional Defiant Disorder, The American Journall of
} 
problemima, kao što su depresija, anksioznost, somatizacijski simptomi te poremećaji hranjenja. ${ }^{28}$

Dosadašnja istraživanja navode da roditeljska toplina, podrška i ljubav imaju pozitivan utjecaj na emocionalnu i socijalnu stabilnost i zrelost djeteta, dok - s druge strane - ravnodušnost, grubost i emocionalna hladnoća pridonose različitim problemima i poteškoćama kod djece te su rizični faktori za razvoj psihopatologije u djetinjstvu i adolescenciji. ${ }^{29}$ Pozivajući se na istraživanja više autora Boričević Maršanić navodi da obitelj može biti protektivan ili rizičan čimbenik u razvoju djeteta, ${ }^{30}$ a pri tomu su narušeni obiteljski odnosi važniji čimbenik rizika od strukture obitelji. ${ }^{31}$

Nakon više od dvije tisuće studija, od kojih su mnoge izravno potaknute teorijom roditeljskog prihvaćanja-odbacivanja (PARTheory), nameće se barem jedan jasan zaključak: djeca svugdje trebaju neki oblik pozitivnog odgovora prihvaćanje od roditelja i drugih bliskih osoba. Kada se ta potreba ne ispuni na zadovoljavajući način, djeca, bez obzira na razlike u kulturi, spolu, dobi, etničkoj pripadnosti ili drugim sličnim obilježjima, postaju, uz ostalo, neprijateljski nastrojena ili agresivna, ovisna ili obrambeno neovisna, prekomjerno oštećena u samopoštovanju i samopouzdanju; emocionalno otuđena i nestabilna, s negativnim svjetonazorima. Uz to, adolescenti i odrasli koji sebe doživljavaju odbačenima čine se zabrinutima i nesigurnima, skloni poremećajima ponašanja, depresivnim ponašanjima, te su sklona zlouporabi droga i alkohola. ${ }^{32}$

\subsection{Suočavanje usmjereno na problem}

Procjena učestalosti ovog stila suočavanja sa stresom istražena je skalom Suočavanje usmjereno na problem. Ova skala ima 16 čestica i raspon od 16 do 80 bodova. Dobiveni rezultati na skali Suočavanje usmjereno na problem su prikazane u tablici 3. Rezultati su podijeljeni u pet kategorija, od nisko (od 27 do 37 bodova) do visoko (od 71 do 80 bodova). Manji broj bodova znači niži stupanj korištenja suočavanja usmjerenog na problem, a veći broj bodova znači viši stupanj korištenja ovog načina suočavanja sa stresom (tablica 4).

\footnotetext{
Psychiatry, 159 (2002) 7, 1214-1224.

${ }^{28}$ Usp. Mark E. PRANGE i dr., Family functioning and psychopathology among adolescents with severe emotional disturbances. Journal of Abnormal Child Psychology, 20 (1992) 1, 83-102; https://doi.org/10.1007/BF00927118.

${ }^{29}$ Usp. Anita VULIĆ-PRTORIĆ, Obiteljske interakcije i psihopatološki simptomi u djece i adolescenata, Suvremena psihologija, 5 (2002) 1, 31-51.

${ }^{30}$ Usp. Vlatka BORIČEVIĆ MARŠANIĆ, Povezanost uskladenosti roditelja u odgoju s emocionalnim i ponašajnim problemima adolescenata, doktorska disertacija, Medicinski fakultet Sveučilišta u Zagrebu, Zagreb, 2011.

${ }^{31}$ Usp. Dale R. HAWLY, Laura DeHAAN, Toward a definition of family resilience. Integrating life-span and family parspectives, Family Process, 35 (1996) 3, 283-298.

${ }^{32}$ Usp. Rohner, Khaleque, Cournoyer, Introduction to parenteral...
} 
Tablica 3. Deskriptivni prikaz rezultata na skali Suočavanje usmjereno na problem

\begin{tabular}{|c|c|c|c|c|c|c|}
\hline $\mathbf{N}$ & Min & Max & M & SD & Koef. varijacije & Cronbach alpha \\
\hline 405 & 27 & 80 & 49,784 & 7,957 & $13 \%$ & 0,85 \\
\hline
\end{tabular}

Rezultati na ovoj skali (tablica 4) ukazuju na činjenicu da je najviše sudionika istraživanja u kategoriji ni niskog, niti visokog stupnja korištenja ovog načina suočavanja sa stresom $(M=49,784)$. U ovoj kategoriji je 42,5 \% sudionika istraživanja. U kategoriji umjereno visokog stupnja korištenja suočavanja sa stresom usmjerenog na problem je $40 \%$ njih, a 8 \% sudionika istraživanja je u kategoriji visokog stupnja korištenja ovog stila suočavanja sa stresom. U kategoriji umjereno niskog stupnja suočavanja sa stresom usmjerenog na problem je $9 \%$, a u kategoriji niskog stupnja ovog stila suočavanja sa stresom je 0,5\% njih. Nizak koeficijent varijacije (13\%) i standardna devijacija $(7,957)$ ukazuju na činjenicu da su sudionici istraživanja davali ujednačene odgovore na ovoj skali. Pouzdanost dobivenih podataka je zadovoljavajuća (Cronbach alpha = 0,85). Broj sudionika istraživanja čiji su podaci obrađeni za ovu skalu je 405, jer 1 sudionik istraživanja nije dao odgovore.

Tablica 4. Raspon rezultata, frekvencije i postotci zastupljenosti sudionika istraživanja na skali Suočavanje usmjereno na problem

\begin{tabular}{|c|c|c|c|c|c|c|}
\hline $\begin{array}{c}\text { Suočavanje usmjereno } \\
\text { na problem }\end{array}$ & Nisko & $\begin{array}{c}\text { Umjereno } \\
\text { nisko }\end{array}$ & $\begin{array}{c}\text { Ni nisko, } \\
\text { niti visoko }\end{array}$ & $\begin{array}{c}\text { Umjereno } \\
\text { visoko }\end{array}$ & Visoko & Suma \\
\hline Raspon rezultata & $27-37$ & $38-48$ & $49-59$ & $60-70$ & $71-80$ & \\
\hline$f$ & 2 & 36 & 171 & 164 & 32 & 405 \\
\hline$\%$ & 0,5 & 9 & 42,5 & 40 & 8 & 100 \\
\hline
\end{tabular}

Kada je suočavanje usmjereno na problem kognitivna, a ne ponašajna aktivnost, tada se ovaj način suočavanja sa stresom koristi učestalije s porastom dobi, odnosno u periodu između adolescencije i mlađe odrasle dobi. Posebice, odnosi se na samopouzdanje u donošenju odluka i korištenje kognitivnih strategija u suočavanju sa stresom. Ovo povećano korištenje suočavanja usmjerenog na problem nastavljaju se čak i u ranoj odrasloj dobi. Kao što bi se očekivalo iz recentnih istraživanja razvoja mozga, korištenje specifičnih kognitivnih strategija - kao pravljenje strategije, odlučivanje, planiranje i razmišljanje - ne čini se rasprostranjenim prije kasne adolescencije ili čak rane odrasle dobi. Zapravo, pubertetska tranzicija označava vrijeme manjeg korištenja suočavanja usmjerenog na problem nego u kasnijem djetinjstvu. Ovaj vremenski ograničeni pad korištenja suočavanja usmjerenog na problem može biti povezan sa specifičnim vremenom pojačanog stresa, što ograničava sposobnosti mlade osobe da usmjeri izravnu pažnju na strategiju suočavanja rješavanjem problema. ${ }^{33}$

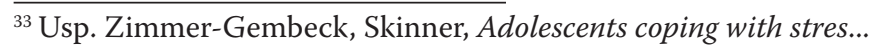


Studija o malezijskim studentima medicine ${ }^{34}$ pokazala je da je suočavanje sa stresom usmjereno na problem na drugom mjestu po učestalosti, iza korištenja religije. Prethodno, jedna studija u Nepalu dala je slične rezultate. ${ }^{35} \mathrm{U}$ usporedbi s prethodnim studijama u Ujedinjenom Kraljevstvu, ${ }^{36}$ koje su izvijestile o korištenju alkohola, duhana i lijekova kao zajedničkih strategija suočavanja studenata medicine, rezultati ove studije su pokazali da je uporaba alkohola ili opojnih tvari najmanje uobičajena strategija suočavanja sa stresom. Nalazi studije provedene u Švedskoj ${ }^{37}$ pokazuju da adolescenti određuju prioritete budućnosti ili sadašnjosti donošenjem odluka, pronalaženjem vlastite privatne sfere da bi se opustili i oporavljali s obitelji i prijateljima, što je aktivan pristup rješavanju stresnih situacija.

\section{Kvaliteta obiteljskih interakcija i suočavanje sa stresom koje je usmjereno na problem}

Međuodnos kvalitete obiteljskih interakcija i suočavanja sa stresom koje je usmjereno na problem istražen je $X^{2}$ - testom za tablice kontingencije kojim su stavljene u odnos dobivene vrijednosti na skalama Zadovoljstvo obiteljskim interakcijama i Suočavanje sa stresom usmjereno na problem (tablica 5). Radi bolje preglednosti i lakšeg razumijevanja rezultati su prikazani u postotnim udjelima pojedinih kategorija u ukupnoj sumi rezultata. Budući da izračunavanje $X^{2}$ - testa podrazumijeva računanje nominalnih vrijednosti, odnosno frekvencija te zbrajanje onih kategorija u kojima je ta vrijednost manja od 5, a vrijednosti u kategorijama 1 i 2 (nisko i umjereno nisko) na skali Zadovoljstvo obiteljskim interakcijama (tablica 2) te dobivena vrijednost u kategoriji 1 (nisko) na skali Suočavanje sa stresom usmjereno na problem (tablica 4) su manje od 5, one su pribrojene kategoriji 3 (ni nisko, niti visoko) na skali Zadovoljstvo obiteljskim interakcijama, odnosno kategoriji 2 (umjereno nisko) na skali Suočavanje sa stresom usmjereno na problem (tablica 5).

Dobiveni rezultati (tablica 5) ukazuju na činjenicu da je suočavanje sa stresom koje je usmjereno na problem češće kod onih sudionika istraživanja koji su zadovoljniji obiteljskim interakcijama. Ovo je vidljivo iz činjenice da 26 \% sudionika istraživanja iz kategorije niskog, umjereno niskog i ni niskog, ni visokog stupnja zadovoljstva obiteljskim interakcijama $(1+2+3)$ ulazi u kategoriju onih sudionika istraživanja koji imaju umjereno visok stupanj suočavanja sa stresom

\footnotetext{
${ }^{34}$ Usp. Muhamad S. B. YUSOFF i dr., A study on stress, stressors and coping strategies among Malaysian medical students, InternatIonal Journal of Students' Research, 1 (2011) 2, 44-50.

${ }^{35}$ Usp. Chandrashekhar SREERAMAREDDY i dr., Psychological morbidity, sources of stress and coping strategies among undergraduate medical students of Nepal, BMC BioMed Central, 26 (2007) 7, 1-8.

${ }^{36}$ Usp. Elizabeth A. GUTHRIE i dr., Embarking upon a medical career. Psychological morbidity in first year medical students, Medical Education, 29 (1995) 5, 337-341.

${ }^{37}$ Usp. Marie WILHSSON i dr., Strategies of Adolescent Girls and Boys for Coping With SchoolRelated Stress, The journal od school nursing, 33 (2016) 5, 374-382.
} 
Tablica 5. Međuodnos kvalitete obiteljskih interakcija i suočavanja sa stresom koje je usmjeren na problem

\begin{tabular}{|c|c|c|c|c|}
\hline & \multicolumn{3}{|c|}{$\begin{array}{c}\text { Zadovoljstvo obiteljskim } \\
\text { interakcijama }\end{array}$} \\
\hline & & $1+2+3$ & 4 & 5 \\
\hline \multirow{5}{*}{ 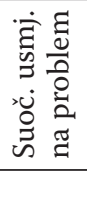 } & $1+2$ & $20 \%$ & $14 \%$ & $6 \%$ \\
\hline & 3 & $49 \%$ & $52 \%$ & $37 \%$ \\
\hline & 4 & $26 \%$ & $26 \%$ & $49 \%$ \\
\hline & 5 & $6 \%$ & $7 \%$ & $8 \%$ \\
\hline & Suma & $100 \%$ & $100 \%$ & $100 \%$ \\
\hline
\end{tabular}

usmjerenog na problem (4). Uz njih, $6 \%$ iz kategorije zadovoljstva obiteljskim interakcijama ulazi u kategoriju onih koji imaju često suočavanje sa stresom koje je usmjereno na problem. Suprotno tome, 26 \% sudionika istraživanja, koji ulaze u kategoriju umjereno visokog stupnja zadovoljstva obiteljskim interakcijama (4), ulazi u kategoriju onih s umjereno visokim stupnjem suočavanja sa stresom usmjerenog na problem. Uz njih, 7 \% sudionika istraživanja koji imaju umjereno visok stupanj zadovoljstva obiteljskim interakcijama (4) ulazi u kategoriju onih sudionika istraživanja koji imaju visok stupanj suočavanja sa stresom usmjerenog na problem (5). Na kraju, 49 \% sudionika istraživanja, koji ulaze u kategoriju visokog stupnja zadovoljstva obiteljskim interakcijama (5) ulazi u kategoriju onih sudionika istraživanja koji imaju umjereno visok stupanj suočavanja sa stresom usmjerenog na problem (4), dok $8 \%$ sudionika istraživanja iz kategorije visokog stupnja zadovoljstva obiteljskim interakcijama ulazi u kategoriju visokog stupnja ovog načina suočavanja sa stresom (5). Naspram njima, 20 \% sudionika istraživanja, koji ulaze u kategoriju niskog, umjereno niskog ili ni niskog, niti visokog stupnja zadovoljstva obiteljskim interakcijama $(1+2+3)$ ulaze u kategoriju niskog ili umjereno niskog stupnja suočavanja sa stresom usmjerenog na problem $(1+2)$, dok $14 \%$ njih iz kategorije umjereno visokog stupnja zadovoljstva obiteljskim interakcijama (4) i 6 \% iz kategorije visokog stupnja zadovoljstva obiteljskim interakcijama ulaze u kategoriju onih koji imaju nizak ili umjereno nizak stupanj suočavanja sa stresom usmjerenog na problem $(1+2)$.

Rezultati $\chi^{2}$ - testa ukazuju na činjenicu da su zadovoljstvo kvalitetom obiteljskih interakcija i suočavanje sa stresom usmjereno na problem statistički značajno povezani ( $x^{2}=27,57$; $\mathrm{p}<0,01$; stupnjevi slobode: 6$)$.

Dobiveni rezultati omogućuju potvrdu hipoteze da adolescenti koji su zadovoljniji obiteljskim interakcijama češće se suočavaju sa stresom usmjereno na problem, a što izravno ili neizravno potvrđuje velik broj studija. ${ }^{38}$ Njihovi rezultati pokazuju da su ponašanja ispitanika koji u suočavanju sa stresom više

\footnotetext{
${ }^{38}$ Usp. Cor MEESTERS, Peter MURIS, Perceived parental rearing behaviours and coping in young adolescents, Personality and Individual Differences, 37 (2004) 3, 513-522.
} 
koriste suočavanje usmjereno na problem bolje prilagođena i funkcionalnija od onih ispitanika koji više koriste suočavanje usmjereno na emocije, a koja su povezana s višom razinom poremećaja u ponašanju, afektinim i socijalnim disfunkcijama. U drugoj studiji ${ }^{39}$ pokazalo se da je suočavanje usmjereno na problem povezano s boljom socijalnom potporom i majčinskom toplinom. Suprotno tome, percepcija majčinske hladnoće i odbijanja pokazala se povezana $\mathrm{s}$ češćim suočavanjem usmjerenim na emocije, distrakcijom i izbjegavanjem.

Jedna je studija pokazala je da su adolescenti koji su svoje roditelje i obiteljske interakcije doživljavali toplijima, više koristili suočavanje sa stresom rješavanjem problema, dok su percipirana roditeljska popustljivost ili zanemarivanje bili povezani s pasivnim stilovima suočavanja. ${ }^{40}$

Drugo je istraživanje utvrdilo da su obiteljski odnosi pozitivno povezani s korištenjem na problem fokusiranog suočavanja sa stresom, manjim brojem simptoma poremećaja prilagodbe te nižim stupnjem depresivnosti. ${ }^{41}$ Rezultati druge studije kažu da adolescenti koji su svoju obitelj opisali kao toplu, podržavajuću i prihvaćajuću češće koriste suočavanje sa stresom usmjereno na problem, dok su loša obiteljska klima i odbacivanje bile pozitivno povezane s korištenjem pasivnih strategija suočavanja sa stresom posebice, u skupini delinkvenata. ${ }^{42}$

Radi znanstvene korektnosti nužno je istaknuti i ograničenja provedenog istraživanja.

Bitno ograničenje ovog istraživanja odnosi se na uzorak koji je prikupljen cluster uzorkovanjem, što ograničava konačnu vrijednost rezultata. U istraživanje su uključeni samo studenti Sveučilišta u Mostaru, a oni ne mogu prezentirati cijelu populaciju mladih. Uz sva zajednička obilježja, oni imaju i svoje specifičnosti po kojima se razlikuju od ostatka te populacije. Sljedeće ograničenje je činjenica da su podaci prikupljeni metodom samoprocjene čiji je nedostatak da su stvarno ponašanje i samoprocjena ponekad u neskladu.

Ipak, uvažavajući sva navedena ograničenja, dobiveni rezultati i njihova interpretacija mogu poslužiti kao dobra znanstvena osnova za poduzimanje novih, specifičnijih istraživanja u polju obiteljske pedagogije posebice, roditeljstva. U tom smislu, eventualna nova istraživanja trebala bi uključiti reprezentativniji uzorak, tj. uzorak koji će uključiti sve adolescentne dobi, te adolescente različitog akademskog statusa. Boljem razumijevanju međuodnosa obiteljskih

\footnotetext{
${ }^{39}$ Usp. isto.

${ }^{40}$ Usp. Jerome B. DUSEK, Maribeth DANKO, Adolescent coping styles and perceptions of parental child rearing, Journal of Adolescent Research, 9 (1994) 4, 412-426.

${ }^{41}$ Usp. Barry M. WAGNER, Patricia COHEN, Judith S. BROOK, Parent-adolescent relationships: Moderators of the effects of stressful life events, Journal of Adolescent Research, 11 (1996) 347-374.

${ }^{42}$ Usp. Vladislav V. RUCHKIN, Martin EISEMANN, Bruno HAGGLOF, Coping styles in delinquent adolescents and controls. The role of personality and parental rearing, Journal of Youth and Adolescence, 28 (1999) 6, 705-717.
} 
interakcija i suočavanja sa stresom usmjerenim na problem doprinijela bi i istraživanja koja bi dala odgovore na pitanja o tome koji su to najvažniji kriteriji i čimbenici koji utječu na formiranje stavova i mišljenja adolescenata o zadovoljstvu njihovim unutarobiteljskim odnosima.

\section{Zaključak}

Ovo istraživanje pošlo je od hipoteze da, u suočavanju sa stresom, adolescenti koji su zadovoljniji obiteljskim interakcijama češće koriste aktivno suočavanje, tj. suočavanje sa stresom usmjereno na problem. Da bi hipoteza bila provjerena prethodno je utvrđen stupanj zadovoljstva adolescenata njihovim obiteljskim interakcijama, te stupanj korištenja suočavanja sa stresom koje je usmjereno na problem. Rezultati ovoga istraživanja pokazali su visok stupanj zadovoljstva adolescenata svojim obiteljskim interakcijama te također, da je najviše njih u kategorijama ni niskog, ni visokog stupnja i umjereno visokog stupnja korištenja suočavanja sa stresom koje je usmjereno na problem. Nakon utvrđivanja ovih činjenica, ove dvije grupe podataka stavljene su u međuodnos $\chi^{2}$ - testom za tablice kontingencije, čime se potvrdila postavljena hipoteza koja glasi: Adolescenti koji su zadovoljniji obiteljskim interakcijama češće koriste suočavanje sa stresom usmjereno na problem.

Rezultati ovog istraživanja u skladu su s drugim istraživanjima u ovom području, a koja naglašavaju značenje i ulogu kvalitetnih obiteljskih interakcija u cjelovitom i zdravom rastu i razvoju pojedinca te ih je u tom smislu potrebno osnaživati. Uvažavajući navedena ograničenja ovoga istraživanja, može se zaključiti da generaliziranje dobivenih rezultata na opću populaciju ne bi bilo opravdano, ali oni mogu biti doprinos razumijevanju međuodnosa zadovoljstva obiteljskim interakcijama i suočavanja sa stresom koje je usmjereno na problem. 


\section{Marko Romić* - Maja Ljubetić*** \\ Adolescents' Active Coping with Stress as a Result of Satisfaction with Family Interactions \\ Summary}

Understanding family relationships is one of the key conditions for a better understanding of the individual and his essential determinants. The quality of family interactions and the family atmosphere determine some essential characteristics of an individual, such as the active or passive way of coping with stress. Actively coping with stress involves choosing strategies directly aimed at solving problems, whereas passive coping refers to, e.g., avoidance, escape to religion, imagination, etc. A study was conducted to determine the relation between the quality of family interactions and ways of coping with adolescent stress on a sample of 406 participants with an average age of 21 years. The results of the study show that the quality of family interactions significantly influences the way adolescents cope with stress, i.e. greater satisfaction with family interactions means that adolescents more frequently use problem-solving strategies to deal with stress.

Key words: adolescents, family interactions, stress, coping with stress.

(na engl. prev. Gorana Duplančić Rogošić)

\footnotetext{
* Marko Romić, PhD, Mental Health Center; Address: Hrvatskih branitelja bb, BiH-88000 Mostar, Bosnia and Hercegovina; E-mail: romicmarko@hotmail.com.

**Maja Ljubetić, PhD, Full Prof., University of Split, Faculty of Humanities and Social Sciences; Address: Poljička cesta 35, HR-21000 Split, Croatia; E-mail: ljubetic@ffst.hr.
} 